\title{
Crosstalk between Smad and Mitogen- Activated Protein Kinases for the Regulation of Apoptosis in Cyclosporine A- Induced Renal Tubular Injury
}

\author{
Hideyuki Iwayama ${ }^{a}$ Tatsuo Sakamoto $^{a}$ Akihiro Nawa $^{b}$ \\ Norishi Uedac \\ Departments of a Pediatrics, ${ }^{b}$ Gynecology and Obstetrics, and ${ }^{c}$ Developmental Pediatrics, \\ Nagoya University Graduate School of Medicine, Nagoya, Japan
}

\section{Key Words}

Apoptosis · Cyclosporine nephrotoxicity $\cdot$ Epidermal growth factor $\cdot$ Mitogen-activated protein kinases $\cdot$ Smad

\begin{abstract}
Background/Aims: It remains elusive whether there is a crosstalk between Smad and mitogenactivated protein kinases (MAPKs) and whether it regulates cyclosporine A (CyA)-induced apoptosis in renal proximal tubular cells (RPTCs). Methods: The effect of CyA on nuclear translocation of Smad2/3 and MAPKs (measured by Western blotting or immunofluorescence) and apoptosis (determined by Hoechst 33258 staining) was examined in HK-2 cells. Results: CyA induced apoptosis at $24 \mathrm{~h}$ and nuclear translocation of phosphorylated (p)-Smad2/3 at $3 \mathrm{~h}$, which was continued till $24 \mathrm{~h}$. CyA enhanced the expression of p-ERK at $1 \mathrm{~h}$, which was continued till $24 \mathrm{~h}$, and of p-p38MAPK at 1-6 h, which returned to control level at $12 \mathrm{~h}$. CyA did not affect JNK. An inhibitor of ERK, PD98059, prevented CyA-induced nuclear translocation of Smad2/3 and apoptosis. An inhibitor of p38MAPK, SB202190, deteriorated CyA-induced nuclear translocation of $p$-Smad2/3. Epidermal growth factor (EGF) activated ERK and p38MAPK but not JNK. EGFinduced activation of MAPKs ameliorated CyA-induced nuclear translocation of $p-S m a d 2 / 3$ and apoptosis. Inhibition of p38MAPK but not of ERK abolished the protective effect of EGF on CyAinduced nuclear translocation of $\mathrm{p}-\mathrm{Smad} 2 / 3$ and apoptosis. Conclusion: Crosstalk between R-Smad and p38MAPK/ERK, but not JNK differentially regulates apoptosis in CyA-induced RPTC injury.




\section{Introduction}

Cyclosporine $\mathrm{A}(\mathrm{CyA})$ has been used for the treatment of various diseases and transplantation. Nephrotoxicity is one of the major adverse events of CyA. Acute CyA nephrotoxicity is caused by renal vasoconstriction, resulting in renal dysfunction, and reversible when CyA administration is diminished or withdrawn [1]. Chronic nephrotoxicity is irreversible and associated with interstitial cell infiltration, fibrosis, or apoptosis in renal proximal tubular cells (RPTCs) [2, 3]. The Bcl-2 family members and caspases have been shown to play a role for CyA-induced apoptosis in RPTCs [3]. However, other cellular and molecular mechanisms of CyA-induced RPTC injury remain elusive, and thus no therapeutic modality preventing the nephrotoxicity is available.

Binding of transforming growth factor- $\beta$ (TGF- $\beta$ ) to TGF $\beta$ RII, its type II membrane receptor, activates type I receptors, resulting in phosphorylation of receptor-activated Smad (R-Smad, Smad2/3) in the cytoplasm $[4,5]$. Phosphorylated (p)-R-Smad binds to common mediator Smad, Smad 4, and these complexes translocate into the nucleus, where they induce transcription of many genes, resulting in the regulation of cell growth, proliferation, and apoptosis [5]. TGF- $\beta$ has been postulated to play a role in CyA-induced nephrotoxicity $[1,2]$ since CyA increased the expression of TGF- $\beta$ in rat kidneys [2] and renal biopsy specimens from patients with CyA nephrotoxicity [4] and release of TGF- $\beta_{1}$ from RPTCs [6]. In addition, TGF- $\beta$-neutralizing antibody ameliorated CyA-induced apoptosis [2].

Mitogen-activated protein kinases (MAPKs), consisting of extracellular signal-regulated kinases 1 and 2 (ERK1/2), p38MAPK, and c-Jun N-terminal kinases (JNK1/2/3), can regulate apoptosis in a variety of cells [5]. Recent studies have shown a crosstalk between Smad and MAPKs in various cells [5]. For example, ERK phosphorylates R-Smad, resulting in inhibition or enhancement of nuclear translocation of R-Smad [5]. p38MAPK phosphorylates $\mathrm{R}-\mathrm{Smad}$, resulting in increased transcription of R-Smad [7]. In addition, JNK regulates nuclear translocation of R-Smad or indirectly affects its phosphorylation [8].

On the other hand, CyA has been shown to reduce the expression of epidermal growth factor (EGF) in rat kidneys [9] and dysfunctioning allograft kidneys [10], suggesting a role for EGF in CyA nephrotoxicity. Binding of EGF to its receptor, EGFR, activates the intrinsic protein tyrosine kinase of EGFR, which regulates downstream cascades, including MAPKs [11]. In fact, EGF can protect apoptosis through activation of MAPKs in various cells in response to stimuli $[9,11]$.

It remains elusive whether there is a crosstalk between Smad and MAPKs, and if so, whether it regulates apoptosis in CyA-induced RPTC injury. It is also unknown whether EGF regulates apoptosis through a crosstalk between Smad and MAPKs in CyA-induced RPTC injury. The present study was undertaken to examine the role of crosstalk between Smad and MAPKs and its modulation by EGF in the regulation of CyA-induced apoptosis in RPTCs.

\section{Materials and Methods}

\section{Materials}

CyA was a gift from Novartis Pharma (Tokyo, Japan). The following reagents and antibodies were purchased: fetal bovine serum, Dulbecco's modified Eagle's medium/nutrient mix F12 (DMEM/F12) and Alexa Fluor ${ }^{\circledR} 488$ goat anti-rabbit antibody (Invitrogen, Carlsbad, Calif., USA); p38MAPK inhibitor, SB202190, and Hoechst 33258 (Sigma, St. Louis, Mo., USA); antibodies for p-Smad2, p-Smad3, Smad2, Smad3, p-ERK1/2, ERK1/2, p-p38MAPK, p38MAPK, p-JNK1/2/3, histone H3, and an inhibitor of ERK, PD98059 (Cell Signaling Technology, Beverly, Mass., USA); recombinant human EGF (R\&D Systems, Minneapolis, Minn., 
USA); Fluoromount (Diagnostic Biosystems, Pleasanton, Calif., USA); protein assay kit (BioRad, Hercules, Calif., USA); Amersham ECL Western blotting detection reagents (GE Healthcare, Little Chalfont, UK), and Lab-Tek II 8-chamber glass slides (Nunc, Naperville, Ill., USA).

\section{Cell Culture}

HK-2 cells (American Type Culture Collection, Manassas, Va., USA), human RPTCs, were maintained at $37^{\circ} \mathrm{C}$ and $5 \% \mathrm{CO}_{2}$ in DMEM/F12, containing $10 \%$ fetal bovine serum, L-glutamine $(2 \mathrm{mM})$, hydrocortisone $(36 \mathrm{ng} / \mathrm{ml})$, and HEPES (20 mM). Cells of passages 4-20 were used.

\section{CyA Treatment}

CyA was prepared as a stock solution $(21 \mathrm{~mm})$ in DMSO. The concentration of CyA $(0.42-42 \mu \mathrm{M})$ was chosen because it is relevant to that in the kidney [6]. Cells were maintained in a serum-free medium for $1 \mathrm{~h}$ and exposed to CyA in the same condition. The final concentration of DMSO, $0.2 \%(\mathrm{v} / \mathrm{v})$, did not induce apoptosis in HK-2 cells.

\section{Measurement of Apoptosis}

Cells cultured on 8-chamber glass slides were washed with phosphate-buffered saline (PBS), fixed with 4\% (v/v) paraformaldehyde in PBS, and stained with Hoechst $33258(1.0 \mu \mathrm{g} /$ $\mathrm{ml})$. The cells were then washed in PBS and mounted with Fluoromount. A minimum of 100 cells per well was counted in a blind fashion. The percentage of apoptotic cells with nuclear condensation and fragmentation was calculated using a confocal fluorescence microscopy.

\section{Immunofluorescence Analysis for Nuclear Translocation of R-Smad}

Cells grown on 8 -chamber slides were washed with PBS, fixed with $4 \%(\mathrm{v} / \mathrm{v})$ paraformaldehyde in PBS, and permeabilized with $0.2 \%(\mathrm{v} / \mathrm{v})$ Triton X-100 in PBS for $10 \mathrm{~min}$, followed by blocking with $0.5 \%(\mathrm{v} / \mathrm{v})$ bovine serum albumin in PBS for $20 \mathrm{~min}$. The primary antibodies for p-Smad2/3 (dilution: 1:100) were added and incubated at $4{ }^{\circ} \mathrm{C}$ overnight. The cells were washed with PBS and incubated with Alexa Fluor 488 goat anti-rabbit antibody (dilution: $1: 100$ ) at room temperature for $1 \mathrm{~h}$. After washing with PBS, the slides were mounted with Fluoromount and analyzed using a confocal fluorescence microscopy.

\section{Preparation of Cell Lysates}

Cells cultured on 6-well plates were washed with PBS and a cytosolic extraction buffer [0.1\% (v/v) Nonidet-40, 10 mM HEPES, $1.5 \mathrm{mM} \mathrm{MgCl}_{2}, 10 \mathrm{mM} \mathrm{KCl}, 1 \mathrm{~mm}$ sodium orthovanadate; $\mathrm{Na}_{3} \mathrm{VO}_{4}, 50 \mathrm{~mm}$ sodium fluoride; $\mathrm{NaF}, 2.5 \mathrm{mM}$ sodium pyrophosphate; $\mathrm{Na}_{4} \mathrm{P}_{2} \mathrm{O}_{7}$, $1 \mathrm{mM} \beta$-glycerophosphate, and 1:50 dilution of a protease inhibitor cocktail] was added to each well. The cells were scraped off the wells, transferred into tubes and centrifuged at $18,000 \mathrm{~g}$ for $5 \mathrm{~min}$ at $4^{\circ} \mathrm{C}$. The supernatants were stored as a cytosolic fraction at $-80^{\circ} \mathrm{C}$ until use.

The remaining pellets were lysed in a nuclear extraction buffer $(20 \mathrm{mM}$ HEPES, $420 \mathrm{mM}$ $\mathrm{NaCl}, 1.5 \mathrm{mM} \mathrm{MgCl}_{2}, 1 \mathrm{~mm}$ EDTA, $1 \mathrm{mM} \mathrm{Na}_{3} \mathrm{VO}_{4}, 50 \mathrm{mM} \mathrm{NaF}, 2.5 \mathrm{~mm} \mathrm{Na}_{4} \mathrm{P}_{2} \mathrm{O}_{7}, 1 \mathrm{~mm}$ $\beta$-glycerophosphate, and 1:50 dilution of a protease inhibitor cocktail) on ice for $30 \mathrm{~min}$, and the samples were centrifuged at $18,000 \mathrm{~g}$ for $30 \mathrm{~min}$ at $4^{\circ} \mathrm{C}$. The resulting supernatants were snap-frozen and stored as a nuclear fraction at $-80^{\circ} \mathrm{C}$ until use. Protein concentrations were measured by the Bio-Rad protein assay kit.

\section{Western Blotting}

Protein $(20 \mu \mathrm{g})$ in Laemmli buffer (62.5 mM Tris-HCl, pH 6.8, 2\% SDS, 10\% glycerol, 5\% $\beta_{2}$-mercaptoethanol, and $0.01 \%$ bromophenol blue) was loaded onto each well. After electro- 
Fig. 1. Effect of CyA on apoptosis. CyA induced apoptosis at $24 \mathrm{~h}$, measured by Hoechst 33258 staining, in a dose-dependent manner. Data are expressed as means \pm SEM. $\mathrm{n}=3,{ }^{*} \mathrm{p}<0.05,{ }^{* *} \mathrm{p}<$ 0.005 , vs. control cells.

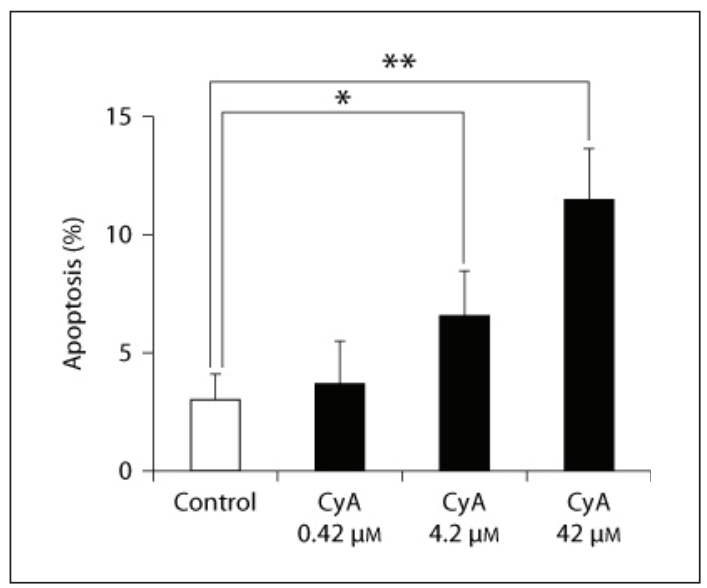

phoresis, the proteins in the gels were transferred to nitrocellulose membrane. The blots were blocked for $1 \mathrm{~h}$ at room temperature in Tris-buffered saline, containing $0.1 \%(\mathrm{v} / \mathrm{v})$ Tween-20, and $5 \%(\mathrm{w} / \mathrm{v})$ nonfat dry milk, and then incubated with primary antibodies (1:1,000 dilution) at $4{ }^{\circ} \mathrm{C}$ overnight. The blots were washed with Tris-buffered saline, incubated with secondary HRP-conjugated antibodies (1:1,000 dilution) for $1 \mathrm{~h}$ at room temperature, and detected using Amersham ECL Western blotting detection reagents.

The ethical committee of our institution approved the study.

\section{Statistical Analysis}

Data are expressed as means \pm SEM and analyzed by one-way ANOVA or by unpaired $t$ test. A value of $\mathrm{p}<0.05$ was considered significant.

\section{Results}

CyA Induces Apoptosis in HK-2 Cells

CyA induced apoptosis in a dose-dependent manner (fig. 1), whereas low concentrations of CyA $(0.42 \mu \mathrm{M})$ failed to induce apoptosis. Based on these data, $42 \mu \mathrm{M}$ of CyA was used in the following experiments if not otherwise indicated.

\section{CyA Induces Nuclear Translocation of R-Smad before Apoptosis}

CyA induced nuclear translocation of p-Smad2/3, measured by Western blotting, at $3 \mathrm{~h}$, which was still noted at $24 \mathrm{~h}$, compared to control cells (fig. 2a). Immunofluorescence analysis confirmed that CyA induced nuclear translocation of p-Smad 2 compared to control cells (fig. 2b).

\section{CyA Activates ERK and p38MAPK but Not JNK}

CyA enhanced the expression of p-ERK at $1 \mathrm{~h}$ in a dose-dependent manner, preceding nuclear translocation of R-Smad and apoptosis, which was still present at $24 \mathrm{~h}$ (fig. 3a). Similarly, CyA increased the expression of p-p38MAPK at 1-6 h in a dose-dependent manner, which returned to control level at $12 \mathrm{~h}$ (fig. 3b). The expression of non-p-ERK or -p38MAPK was similar between control and CyA-treated cells. CyA did not affect the expression of p-JNK (data not shown). 


\begin{tabular}{l|l}
\hline Nephron Extra 2011;1:178-189 \\
\hline DOI: 10.1159/000333014 & $\begin{array}{l}\text { @ 2011 S. Karger AG, Basel } \\
\text { www.karger.com/nne }\end{array}$ \\
Published online: October 26, 2011 &
\end{tabular}

Fig. 2. CyA induces nuclear translocation of R-Smad. a CyA $(42 \mu \mathrm{M})$ induced nuclear translocation of phosphorylated (p)-Smad $2 / 3$ at $3 \mathrm{~h}$, measured by Western blotting, preceding apoptosis, which persisted till $24 \mathrm{~h}$, compared to control cells. b Immunofluorescence analysis confirmed that CyA induced nuclear translocation of $\mathrm{p}-\mathrm{Smad} 2$ at $6 \mathrm{~h}$ (CyA, right panel), compared to control cells (left panel). Arrows indicate CyA-induced nuclear translocation of $\mathrm{p}-\mathrm{Smad} 2$. Data are representative of 3 independent experiments.

Iwayama et al.: Smad/MAPKs in CyA-Induced Tubular Apoptosis
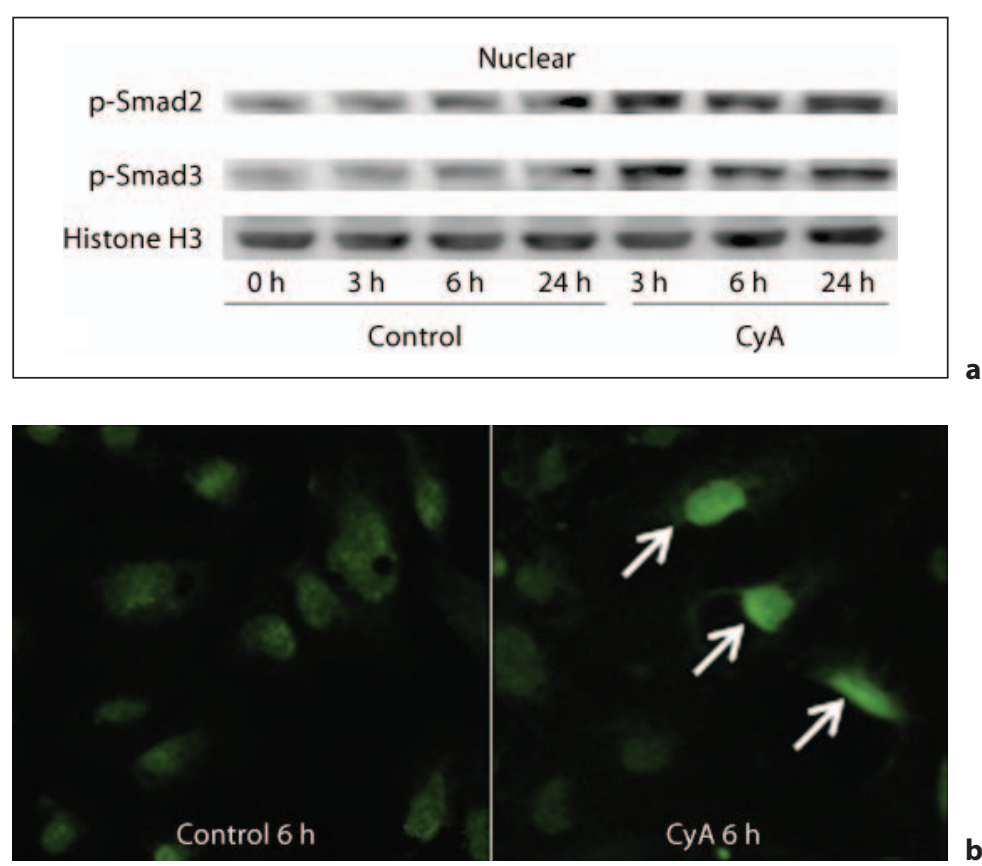

Fig. 3. Time- and dose-dependent effect of CyA on MAPK activity. a CyA (10.5-42 $\mu \mathrm{M})$ dosedependently enhanced p-ERK expression at $1 \mathrm{~h}$, preceding nuclear translocation of Smad2/3, which persisted till $24 \mathrm{~h}$, compared to control cells (C). b CyA increased the expression of $p$ p38MAPK at $1-6 \mathrm{~h}$ in a dose-dependent manner, which returned to control level at $12 \mathrm{~h}$. The expression of non-p-ERK and -p38MAPK did not differ between control and CyA-treated cells. Data are representative of 3 independent experiments.
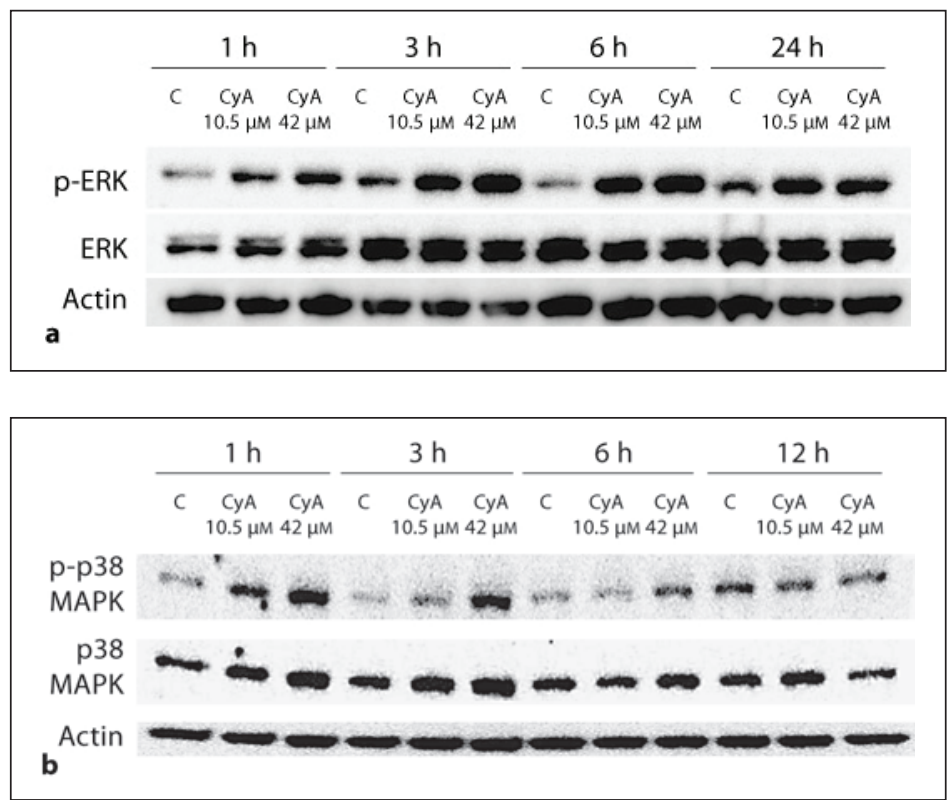

Inhibition of $338 M A P K$ Deteriorates but That of ERK Ameliorates CyA-Induced Nuclear Translocation of R-Smad

As previously shown, CyA increased the expression of p-Smad2 compared to control cells (fig. 4, lane 2). An inhibitor of ERK, PD98059, ameliorated CyA-induced nuclear translocation of p-Smad2 (fig. 4, lane 7). In contrast, an inhibitor of p38MAPK, SB202190, deteriorated nuclear translocation of p-Smad2 in control and CyA-treated cells (fig. 4, lanes 4, 5). We confirmed that PD98059 and SB202190 inhibited the expression of p-ERK and p-p38MAPK, respectively, in control and CyA-treated cells (data not shown). 


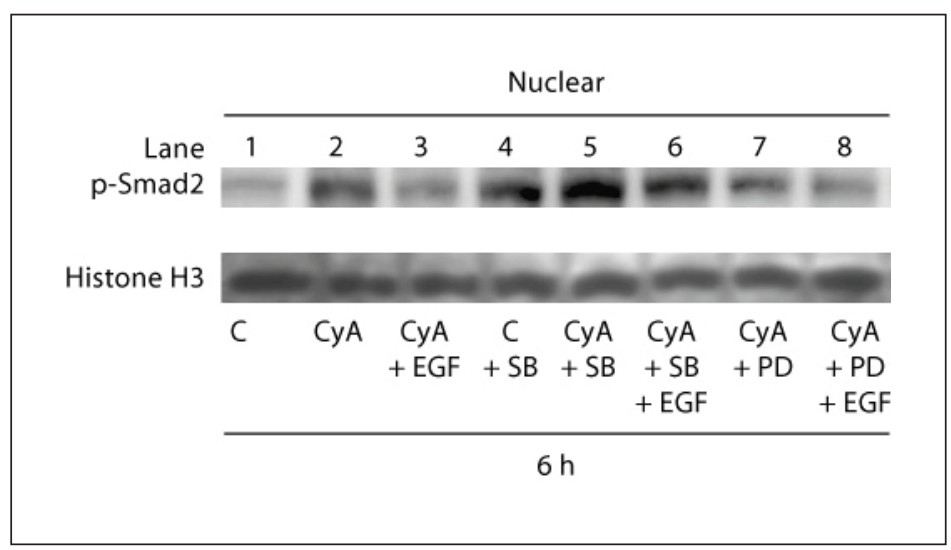

Fig. 4. Effect of inhibition of MAPKs in the presence or absence of EGF on CyA-induced nuclear translocation of R-Smad. CyA $(42 \mu \mathrm{M})$ increased the expression of p-Smad2 (lane 2) at $6 \mathrm{~h}$, measured by Western blotting, compared to control cells (C, lane 1). SB202190 (SB; $20 \mu \mathrm{M})$ deteriorated nuclear translocation of p-Smad2 in both control (lane 4) and CyA-treated cells (lane 5), whereas PD98059 (PD; $20 \mu \mathrm{M})$ ameliorated nuclear translocation of p-Smad2 in CyA-treated cells (lane 7). EGF (20 ng/ml) ameliorated CyAinduced nuclear translocation of p-Smad2 (lane 3), which was abolished by SB202190 (lane 6) but not by PD98059 (lane 8).

Fig. 5. Effect of inhibition of MAPKs on CyA-induced apoptosis. PD98059 (PD; $20 \mu \mathrm{M})$ but not SB202190 (SB; $20 \mu \mathrm{M})$ ameliorated CyA (42 $\mu \mathrm{M})$-induced apoptosis at $24 \mathrm{~h}$. Data are expressed as means \pm SEM. $\mathrm{n}=3$, ${ }^{*} \mathrm{p}<0.02,{ }^{* *} \mathrm{p}<0.001$.

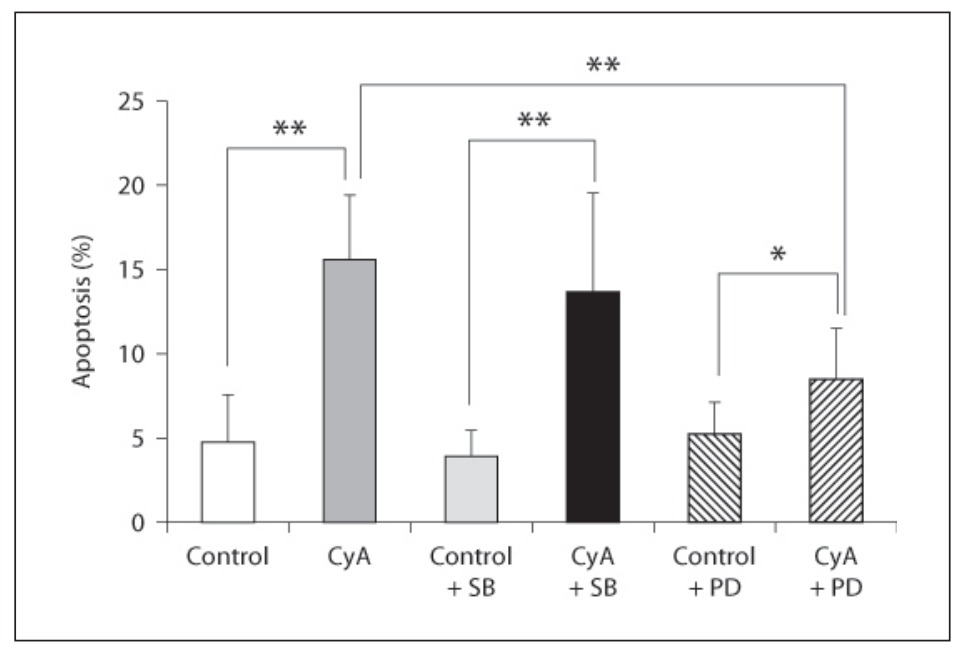

Inhibition of ERK but Not of p38MAPK Ameliorates CyA-Induced Apoptosis

An inhibitor of ERK, PD98059, ameliorated CyA-induced apoptosis (fig. 5), suggesting that inhibition of ERK prevents CyA-induced apoptosis through inhibition of R-Smad. In contrast, an inhibitor of p38MAPK, SB202190, failed to prevent CyA-induced apoptosis.

\section{EGF Activates ERK and p38MAPK but Not JNK}

To determine whether enhanced activation of MAPKs modulates CyA-induced apoptosis in RPTCs, we first examined whether EGF activates MAPKs in HK-2 cells. EGF enhanced the expression of p-ERK and p-p38MAPK in control and CyA-treated cells (fig. 6a, b). However, EGF did not affect JNK activity in control and CyA-treated cells (data not shown). 
Fig. 6. Effect of EGF on MAPK activity. EGF (20 ng/ml) enhanced the expression of $\mathrm{p}$-ERK (a) and p-p38MAPK (b) at 3-6 h in control (C) and CyA-treated cells. Data are representative of 3 independent experiments.
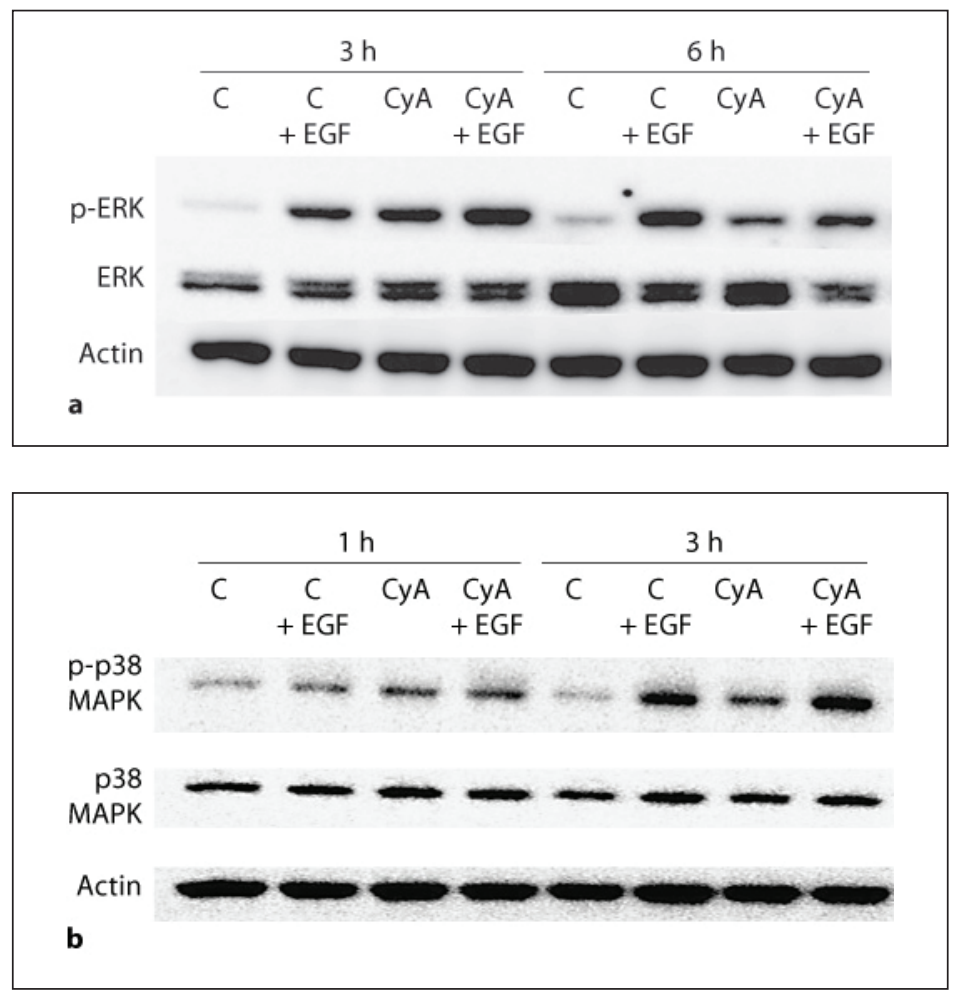

EGF Ameliorates CyA-Induced Apoptosis through Activation of p38MAPK in a Smad-Dependent Pathway

EGF ameliorated CyA-induced nuclear translocation of p-Smad2, measured by Western blotting (fig. 4, lane 3). This was confirmed by immunofluorescence analysis (fig. 7c). The protective effect of EGF on CyA-induced nuclear translocation of $\mathrm{p}-\mathrm{Smad} 2 / 3$ was not abolished by inhibition of ERK (fig. 4, lane 8 , fig. 7f). In contrast, it was abolished by inhibition of p38MAPK (fig. 4, lane 6, fig. 7e), suggesting that p38MAPK inhibits R-Smad in CyAinduced RPTC injury.

EGF significantly prevented CyA-induced apoptosis (fig. 8). Inhibition of p38MAPK but not of ERK abolished the protective effect of EGF on CyA-induced apoptosis, suggesting that EGF prevents CyA-induced apoptosis in RPTCs through activation of p38MAPK in a Smaddependent pathway.

\section{Discussion}

The effect of CyA on activation of MAPKs varies with the type of renal tubular cells in response to stimuli. CyA activated ERK in LLC-PK1 cells [12], and both ERK and p38MAPK in cortical collecting duct cells [13], whereas it activated ERK but not p38MAPK in MadinDarby canine kidney cells [6]. CyA inhibited parathyroid hormone-induced ERK activation in mouse distal convoluted tubule cells [14]. Preconditioning of rat kidneys with CyA followed by exposure to ischemia/reperfusion increased ERK activity, but decreased p38MAPK and JNK activity [15]. In the present study, we found that CyA activated both ERK and p38MAPK but not JNK, preceding nuclear translocation of R-Smad and apoptosis in RPTCs. 

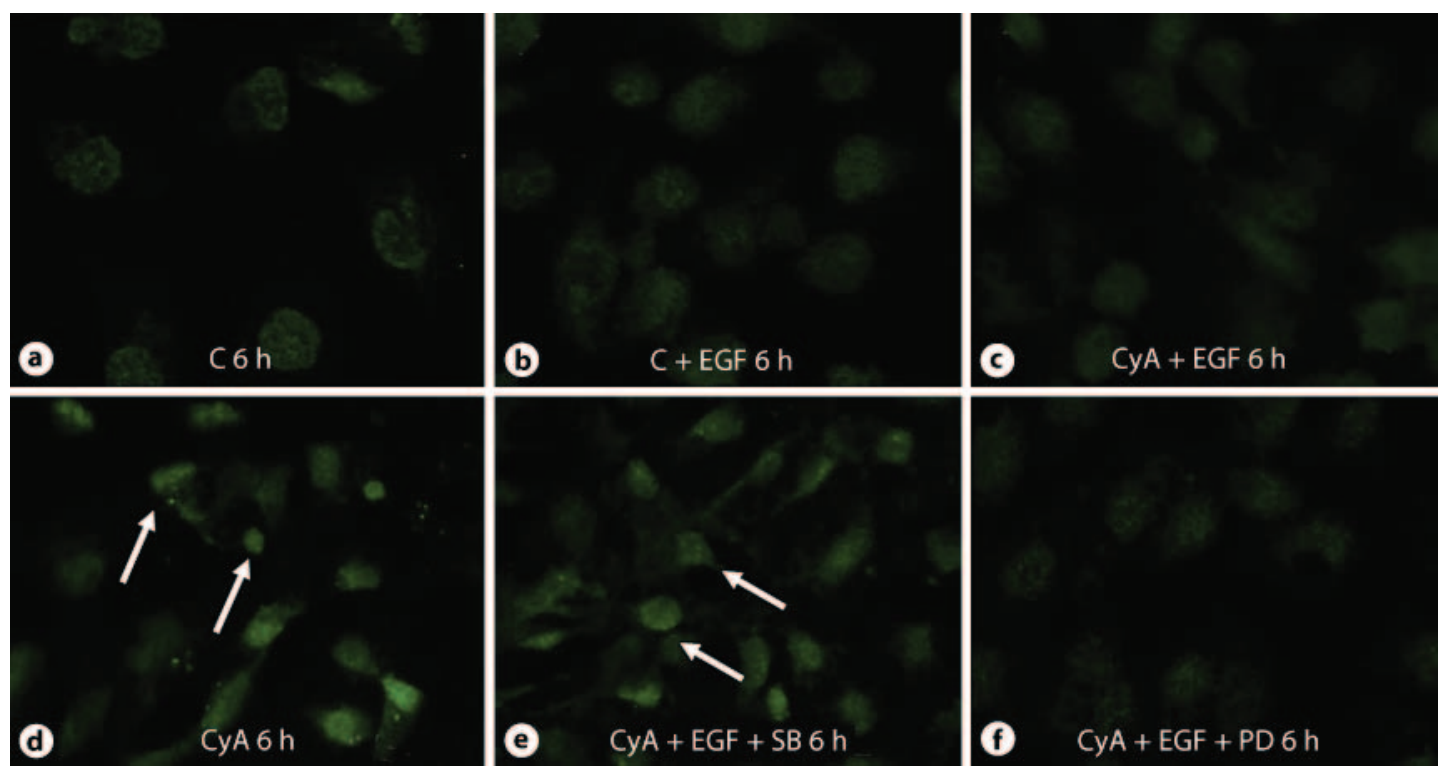

Fig. 7. Immunofluorescence analysis for the effect of EGF on CyA-induced nuclear translocation of R-Smad and its modulation by inhibition of MAPKs. Immunofluorescence analysis showed that CyA induced nuclear translocation of p-Smad 3 at $6 \mathrm{~h}$ (d, arrows) compared to control cells (a). EGF did not affect nuclear translocation of p-Smad3 in control cells (b). EGF ameliorated CyA-induced translocation of p-Smad3 (c), which was abolished by SB202190 (e, arrows) but not by PD98059 (f). Data are representative of 3 independent experiments.

Fig. 8. Effect of EGF in the presence or absence of inhibition of MAPKs on CyA-induced apoptosis. EGF (20 $\mathrm{ng} / \mathrm{ml})$ rescued CyA (42 $\mu \mathrm{M})$-induced apoptosis at 24 h. SB202190 (SB; $20 \mu \mathrm{M})$ but not PD98059 (PD; $20 \mu \mathrm{M})$ abolished the protective effect of EGF on CyA-induced apoptosis. Data are expressed as means \pm SEM. $\mathrm{n}=3,{ }^{*} \mathrm{p}<0.02,{ }^{* *} \mathrm{p}<0.001$.

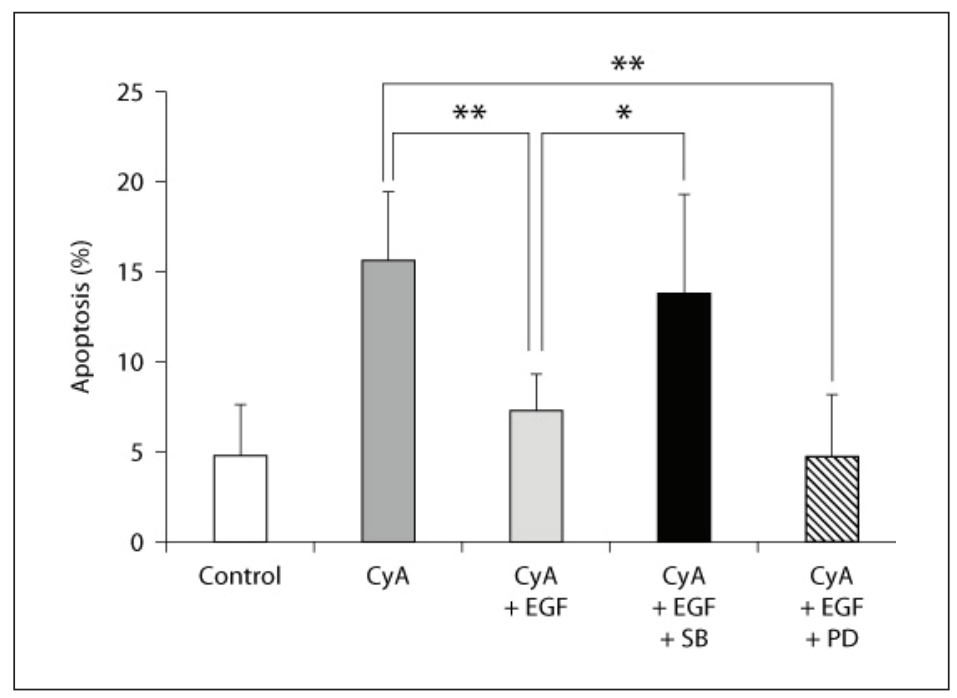

It is well known that ERK functions as antiapoptotic and p38MAPK as proapoptotic in a variety of cells in response to stimuli [16]. It has recently been shown that ERK functions as proapoptotic and p38MAPK as antiapoptotic $[17,18]$. Crosstalk between R-Smad and MAPKs differentially regulates apoptosis in various cells [5], including kidney cells [19, 20], in response to TGF- $\beta_{1}$. ERK functions as antiapoptotic by inhibiting R-Smad in other cells [5]. Regarding crosstalk between R-Smad and ERK in RPTCs, ERK did not affect TGF- $\beta_{1^{-}}$ 
induced nuclear translocation of p-Smad3 in human HK-2 cells [21] or rat RPTCs [22]. However, it remains elusive whether there is a crosstalk between R-Smad and MAPKs and its role for the regulation of apoptosis in CyA-induced RPTC injury. Our data show that inhibition of ERK ameliorates CyA-induced apoptosis by inhibiting nuclear translocation of Smad2/3, suggesting that ERK functions as proapoptotic through activation of R-Smad in CyA-induced RPTC injury. This is further supported by the fact that inhibition of ERK did not abolish the protective effect of EGF, which activated ERK and p38MAPK [23, 24], on CyA-induced Smad signaling and apoptosis in RPTCs. Our finding is compatible with the studies showing that inhibition of ERK ameliorated apoptosis by inhibiting nuclear translocation of R-Smad in other cells in response to different stimuli [25, 26]. Inhibition of ERK also downregulated TGF- $\beta_{1}$-induced Smad 2 mRNA expression in mesenchymal stem cells [27]. Our data, together with previous data, suggest a crosstalk between R-Smad and ERK and that ERK functions as proapoptotic by activating R-Smad in CyA-induced RPTC injury.

In many cells, p38MAPK phosphorylates R-Smad, resulting in enhanced transactivational potential of R-Smad [5], and induces apoptosis [16]. It has recently been shown that p38MAPK functions as antiapoptotic in response to stimuli $[16,18]$. We found that inhibition of p38MAPK deteriorated nuclear translocation of p-Smad 2 in both control and CyAtreated cells, suggesting a crosstalk between R-Smad and p38MAPK in RPTCs. In addition, EGF-induced MAPK activation ameliorated CyA-induced nuclear translocation of Smad2/3 and apoptosis, which was abolished by inhibition of p38MAPK but not of ERK. Taken together, our data suggest that p38MAPK functions as antiapoptotic by inhibiting nuclear translocation of both Smad2 and Smad3 in CyA-induced RPTC injury. Inhibition of p38MAPK has been shown to upregulate TGF- $\beta_{1}$-induced mRNA expression or nuclear translocation of Smad2, but downregulate those of Smad3 in other cells [27, 28]. Our data, together with previous data, suggest that $\mathrm{p} 38 \mathrm{MAPK}$ may differentially regulate R-Smad, depending on the cell type and stimuli. Another explanation of our data may be that p38MAPK may inhibit nuclear translocation of R-Smad by upregulating inhibitory Smad [29].

It is unknown why the control cells treated with an inhibitor of p38MAPK, which showed increased nuclear translocation of p-Smad2, did not undergo apoptosis. They may have a higher threshold for triggering Smad signaling cascades than that under stimulated condition $[30,31]$. The endogenous Smad2/Smad3 ratio [31,32] and the balance between R-Smad and inhibitory Smad [33] or other antiapoptotic machineries [34], which can regulate apoptosis, may be well maintained in the cells under unstimulated conditions. These factors may account for the observation that the control cells treated with an inhibitor of p38MAPK did not undergo significant apoptosis.

Regarding RPTC injury, TGF- $\beta_{1}$-induced activation of p38MAPK failed to affect R-Smad in HK-2 cells maintained in a 2-day serum-free condition [21]. Long-term serum deprivation may influence cellular behavior. An inhibitor of p38MAPK, FR167653, counteracted glomerulosclerosis and interstitial fibrosis in CyA-induced allograft nephropathy in the rat, with donor kidneys being subjected to ischemic injury before CyA treatment [35]. The study used the different experimental conditions and did not evaluate apoptosis. Since cellular response varies with cell type, species, or stimulus, these factors may be attributable to the contradictory results.

Our study suggests that EGF prevents CyA-induced Smad signaling and apoptosis through activation of p38MAPK in RPTCs. In fact, CyA failed to induce apoptosis in human RPTCs in serum containing growth factors such as EGF [36]. EGF ameliorated apoptosis through ERK-dependent but p38MAPK-independent pathways in rat hepatocytes [37]. Regarding the effect of EGF on Smad signaling, EGF phosphorylated R-Smad in various cells $[38,39]$, and inhibition of MEK1 (MAPK/ERK kinase 1), upstream of ERK pathways, prevented EGF-induced phosphorylation of R-Smad [38]. EGF induced TGFßRII expression, 
which may enhance Smad signaling, and this effect was ameliorated by inhibition of p38MAPK but not of ERK in human dermal fibroblasts [40]. On the other hand, EGF failed to affect R-Smad, but rather stabilized Smad corepressor TGIF [41]. In support of our findings, EGF ameliorated TGF- $\beta_{1}$-induced nuclear translocation of $\mathrm{p}$-Smad3 in granulosa cells [42]. EGF also upregulated inhibitory Smad [43], which may inhibit R-Smad. Our data, together with these data, suggest that EGF antagonizes CyA-induced Smad signaling through activation of p38MAPK and that the administration of exogenous survival growth factors, such as EGF, or the modality of regulating EGFR may be the successful strategy for preventing CyA nephrotoxicity [3]. In fact, EGF accelerated regeneration of RPTCs after exposure to other nephrotoxic agents [44], and inhibition of EGFR induced apoptosis in renal collecting duct cells [45].

In summary, our study suggests a crosstalk between R-Smad and ERK/p38MAPK, but not JNK, in the regulation of apoptosis and that p38MAPK functions as an antiapoptotic factor by inhibiting R-Smad, whereas ERK functions as proapoptotic by activating R-Smad in CyA-induced RPTC injury. EGF, which activates ERK and p38MAPK, but not JNK, ameliorates CyA-induced nuclear translocation of R-Smad and apoptosis through activation of p38MAPK in RPTCs.

\section{Acknowledgments}

We thank Mrs. M. Miyake for her technical assistance. This study has been supported by the Aichi Kidney Foundation and the Nagono Medical Foundation.

\section{Disclosure Statement}

There is no conflict of interest.

\section{References}

1 Naesens M, Kuypers DR, Sarwal M: Calcineurin inhibitor nephrotoxicity. Clin J Am Soc Nephrol 2009;4:481-508.

2 Ling H, Li X, Jha S, Wang W, Karetskaya L, Pratt B, Ledbetter S: Therapeutic role of TGF- $\beta$-neutralizing antibody in mouse cyclosporin A nephropathy: morphologic improvement associated with functional preservation. J Am Soc Nephrol 2003;14:377-388.

3 Servais H, Ortiz A, Devuyst O, Denamur S, Tulkens PM, Mingeot-Leclercq MP: Renal cell apoptosis induced by nephrotoxic drugs: cellular and molecular mechanisms and potential approaches to modulation. Apoptosis 2008;13:11-32.

4 Khanna A, Plummer M, Bromberek C, Bresnahan B, Hariharan S: Expression of TGF- $\beta$ and fibrogenic genes in transplant recipients with tacrolimus and cyclosporine nephrotoxicity. Kidney Int 2002;62:2257-2263.

5 Javelaud D, Mauviel A: Crosstalk mechanisms between the mitogen-activated protein kinase pathways and Smad signaling downstream of TGF- $\beta$ : implications for carcinogenesis. Oncogene 2005; 24:5742-5750.

6 Feldman G, Kiely B, Martin N, Ryan G, McMorrow T, Ryan MP: Role for TGF- $\beta$ in cyclosporineinduced modulation of renal epithelial barrier function. J Am Soc Nephrol 2007;18:1662-1671.

7 Kamaraju AK, Roberts AB: Role of Rho/ROCK and p38 MAP kinase pathways in transforming growth factor- $\beta$-mediated Smad-dependent growth inhibition of human breast carcinoma cells in vivo. J Biol Chem 2005;280:1024-1036. 
8 Jablonska E, Markart P, Zakrzewicz D, Preissner KT, Wygrecka M: Transforming growth factor- $\beta_{1}$ induces expression of human coagulation factor XII via Smad3 and JNK signaling pathways in human lung fibroblasts. J Biol Chem 2010;285:11638-11651.

9 Yang CW, Lee SH, Lim SW, Jung JY, Kim WY, Kim HW, Choi BS, Li C, Cha JH, Kim YS, Kim J, Bang BK: Cyclosporine or FK506 decrease mature epidermal growth factor protein expression and renal tubular regeneration in rat kidneys with ischemia/reperfusion injury. Nephron 2002;92:914-921.

10 Di Paolo S, Gesualdo L, Stallone G, Ranieri E, Schena FP: Renal expression and urinary concentration of EGF and IL-6 in acutely dysfunctioning kidney transplanted patients. Nephrol Dial Transplant 1997;12:2687-2693.

11 Henson ES, Gibson SB: Surviving cell death through epidermal growth factor (EGF) signal transduction pathways: implications for cancer therapy. Cell Signal 2006;18:2089-2097.

12 Martin-Martin N, Ryan G, McMorrow T, Ryan MP: Sirolimus and cyclosporine A alter barrier function in renal proximal tubular cells through stimulation of ERK1/2 signaling and claudin-1 expression. Am J Physiol Renal Physiol 2010;298:F672-F682.

13 Zhang Y, Lin DH, Wang ZJ, Jin Y, Yang B, Wang WH: K restriction inhibits protein phosphatase 2B (PP2B) and suppression of PP2B decreases ROMK channel activity in the CCD. Am J Physiol Cell Physiol 2008;294:C765-C773.

14 Kim SJ, Kang HS, Jeong CW, Park SY, Kim IS, Kim NS, Kim SZ, Kwak YG, Kim JS, Quamme GA: Immunosuppressants inhibit hormone-stimulated $\mathrm{Mg}^{2+}$ uptake in mouse distal convoluted tubule cells. Biochem Biophys Res Commun 2006;341:742-748.

15 Yang CW, Ahn HJ, Jung JY, Kim WY, Li C, Choi BS, Kim HW, Kim YS, Moon IS, Kim J, Bang BK: Preconditioning with cyclosporine A or FK506 differentially regulates mitogen-activated protein kinase expression in rat kidneys with ischemia/reperfusion injury. Transplantation 2003;75:20-24.

16 Wada T, Penninger JM: Mitogen-activated protein kinases in apoptosis regulation. Oncogene 2004; 23:2838-2849.

17 Cagnol S, Chambard JC: ERK and cell death: Mechanisms of ERK-induced cell death-apoptosis, autophagy and senescence. FEBS J 2010;277:2-21.

18 Thornton TM, Rincon M: Non-classical p38Map kinase functions: cell cycle checkpoints and survival. Int J Biol Sci 2009;5:44-52.

19 Dai C, Yang J, Liu Y: Transforming growth factor- $\beta_{1}$ potentiates renal tubular epithelial cell death by a mechanism independent of Smad signaling. J Biol Chem 2003;278:12537-12545.

20 Nicolás FJ, Lehmann K, Warne PH, Hill CS, Downward J: Epithelial to mesenchymal transition in Madin-Darby canine kidney cells is accompanied by down-regulation of Smad3 expression, leading to resistance to transforming growth factor- $\beta$-induced growth arrest. J Biol Chem 2003;278:32513256.

21 Zhang M, Fraser D, Phillips A: ERK, p38, and Smad signaling pathways differentially regulate transforming growth factor- $\beta_{1}$ autoinduction in proximal tubular epithelial cells. Am J Pathol 2006;169: $1282-1293$.

22 Nakagawa T, Lan HY, Glushakova O, Zhu HJ, Kang DH, Schreiner GF, Böttinger EP, Johnson RJ, Sautin YY: Role of ERK1/2 and p38 mitogen-activated protein kinases in the regulation of thrombospondin-1 by TGF- $\beta 1$ in rat proximal tubular cells and mouse fibroblasts. J Am Soc Nephrol 2005; 16:899-904.

23 Baer PC, Geiger H: Differential effects of growth factors on human renal early distal tubular cells in vitro. Kidney Blood Press Res 2006;29:225-230.

24 Tian YC, Chen YC, Chang CT, Hung CC, Wu MS, Phillips A, Yang CW: Epidermal growth factor and transforming growth factor- $\beta 1$ enhance HK-2 cell migration through a synergistic increase of matrix metalloproteinase and sustained activation of ERK signaling pathway. Exp Cell Res 2007;313: 2367-2377.

25 Kretzschmar M, Doody J, Timokhina I, Massagué J: A mechanism of repression of TGF $\beta /$ Smad signaling by oncogenic Ras. Genes Dev 1999;13:804-816.

26 Heger J, Schiegnitz E, von Waldthausen D, Anwar MM, Piper HM, Euler G: Growth differentiation factor 15 acts anti-apoptotic and pro-hypertrophic in adult cardiomyocytes. J Cell Physiol 2010;224: $120-126$.

27 Li J, Zhao Z, Liu J, Huang N, Long D, Wang J, Li X, Liu Y: MEK/ERK and p38 MAPK regulate chondrogenesis of rat bone marrow mesenchymal stem cells through delicate interaction with TGF- $\beta 1 /$ Smads pathway. Cell Prolif 2010;43:333-343. 
28 Wang FM, Hu T, Tan H, Zhou XD: p38 mitogen-activated protein kinase affects transforming growth factor- $\beta$ /Smad signaling in human dental pulp cells. Mol Cell Biochem 2006;291:49-54.

29 Saika S: TGF- $\beta$ signal transduction in corneal wound healing as a therapeutic target. Cornea 2004; 23(8 suppl 1):S25-S30.

30 Wang D, Shen Q, Chen YQ, Wang MH: Collaborative activities of macrophage-stimulating protein and transforming growth factor- $\beta 1$ in induction of epithelial to mesenchymal transition: roles of the RON receptor tyrosine kinase. Oncogene 2004;23:1668-1680.

31 Kohn EA, Du Z, Sato M, Van Schyndle CMH, Welsh MA, Yang YA, Stuelten CH, Tang B, Ju W, Bottinger EP, Wakefield LM: A novel approach for the generation of genetically modified mammary epithelial cell cultures yields new insights into TGF $\beta$ signaling in the mammary gland. Breast Cancer Res 2010;12:R83.

32 Kim GS, Kim HA, Jong HS, Park JH, Kim NK, Hong SH, Kim TY, Bang YJ: The endogenous ratio of Smad2 and Smad3 influences the cytostatic function of Smad3. Mol Biol Cell 2005;16:4672-4683.

33 Gonzalez AV, Le Bellego F, Ludwig MS: Imbalance of receptor-regulated and inhibitory Smads in lung fibroblasts from bleomycin-exposed rats. Am J Respir Cell Mol Biol 2007;36:206-212.

34 Conery AR, Cao Y, Thompson EA, Townsend CM Jr, Ko TC, Luo K: Akt interacts directly with Smad3 to regulate the sensitivity to TGF- $\beta$-induced apoptosis. Nat Cell Biol 2004;6:366-372.

35 Wada T, Azuma H, Furuichi K, Sakai N, Kitagawa K, Iwata Y, Matsushima K, Takahara S, Yokoyama H, Kaneko S: Reduction in chronic allograft nephropathy by inhibition of p38 mitogen-activated protein kinase. Am J Nephrol 2006;26:319-325.

36 Bakker RC, van Kooten C, van de Lagemaat-Paape ME, Daha MR, Paul LC: Renal tubular epithelial cell death and cyclosporin A. Nephrol Dial Transplant 2002;17:1181-1188.

37 Roberts RA, James NH, Cosulich SC: The role of protein kinase B and mitogen-activated protein kinase in epidermal growth factor and tumor necrosis factor $\alpha$-mediated rat hepatocyte survival and apoptosis. Hepatology 2000;31:420-427.

38 de Caestecker MP, Parks WT, Frank CJ, Castagnino P, Bottaro DP, Roberts AB, Lechleider RJ: Smad2 transduces common signals from receptor serine-threonine and tyrosine kinases. Genes Dev 1998; 12:1587-1592.

39 Diamond ME, Sun L, Ottaviano AJ, Joseph MJ, Munshi HG: Differential growth factor regulation of $\mathrm{N}$-cadherin expression and motility in normal and malignant oral epithelium. J Cell Sci 2008;121: 2197-2207.

40 Yamane K, Asano Y, Tamaki K, Ihn H: Epidermal growth factor up-regulates transforming growth factor- $\beta$ receptor type II in human dermal fibroblasts via p38 mitogen-activated protein kinase pathway. Biochem Biophys Res Commun 2007;352:69-77.

41 Yang S, Nugent MA, Panchenko MP: EGF antagonizes TGF- $\beta$-induced topoelastin expression in lung fibroblasts via stabilization of Smad corepressor TGIF. Am J Physiol Lung Cell Mol Physiol 2008; 295:L143-L151.

42 Yang P, Roy SK: Transforming growth factor $\beta 1$ stimulated DNA synthesis in the granulosa cells of preantral follicles: negative interaction with epidermal growth factor. Biol Reprod 2006;75:140-148.

43 Afrakhte M, Morén A, Jossan S, Itoh S, Sampath K, Westermark B, Heldin CH, Heldin NE, ten Dijke P: Induction of inhibitory Smad6 and Smad7 mRNA by TGF- $\beta$ family members. Biochem Biophys Res Commun 1998;249:505-511.

44 Coimbra TM, Cieslinski DA, Humes HS: Epidermal growth factor accelerates renal repair in mercuric chloride nephrotoxicity. Am J Physiol Renal Physiol 1990;259:F438-F443.

45 Zhang Z, Pascuet E, Hueber PA, Chu LL, Bichet DG, Lee TC, Threadgill DW, Goodyer P: Targeted inactivation of EGF receptor inhibits renal collecting duct development and function. J Am Soc Nephrol 2010;21:573-578. 